Brazilian Journal

of Chemical

ISSN 0104-6632

Engineering

Printed in Brazil

www.abeq.org.br/bjche

Vol. 34, No. 02, pp. 451 - 457, April - June, 2017

dx.doi.org/10.1590/0104-6632.20170342s20160107

\title{
FUNCTIONALIZED AGAROSE AS AN EFFECTIVE AND NOVEL MATRIX FOR IMMOBILIZING Cicer arietinum $\beta$-GALACTOSIDASE AND ITS APPLICATION IN LACTOSE HYDROLYSIS
}

\author{
R. Satar ${ }^{1}$ and S. A. Ansari ${ }^{*}$ \\ ${ }^{1}$ Department of Biochemistry, Ibn Sina National College for Medical Sciences, \\ Jeddah-21418, Kingdom of Saudi Arabia. \\ ${ }^{2}$ Center of Excellence in Genomic and Medicine Research, King Abdulaziz University, \\ Jeddah-21589, Kingdom of Saudi Arabia. \\ Phone: (0)02-6401000 (Ext-25478), Fax: +966 26952521, Mobile: +966 581482720 \\ E-mail: saansari@kau.edu.sa
}

(Submitted: December 22, 2015; Revised: February 14, 2015; Accepted: March 14, 2016)

\begin{abstract}
The present study demonstrates the immobilization of $\beta$-galactosidase from Cicer arietinum on a simple and inexpensive matrix, glutaraldehyde functionalized agarose (GFA), to suggest its potential application in hydrolyzing whey lactose in biotechnology industries. The designed matrix provided large surface area for the immobilization of $\beta$-galactosidase, apart from exhibiting greater biocatalytic activity in terms of selectivity, loading and stability. GFA retained $83 \%$ enzyme activity as a result of immobilization. Soluble and GFA bound Cicer arietinum $\beta$-galactosidase showed the same $\mathrm{pH}$ and temperature-optima at $\mathrm{pH} 5.0$ and at $50{ }^{\circ} \mathrm{C}$, respectively. However, immobilized enzyme exhibited a greater fraction of activity at both acidic and basic $\mathrm{pH}$, and at higher temperature ranges. GFA bound enzyme lost only $20 \%$ enzyme in the presence of $3 \%$ galactose, and retained $70 \%$ activity even after its sixth repeated use. Immobilized enzyme showed pronounced lactose hydrolysis from whey in batch processes at $55^{\circ} \mathrm{C}$ as compared to enzyme in solution.
\end{abstract}

Keywords: agarose; $\beta$-galactosidase; Cicer arietinum; glutaraldehyde; whey hydrolysis

Abbreviations: GFA, glutaraldehyde functionalized agarose; $\mathrm{S} \beta \mathrm{G}$, soluble $\beta$-galactosidase; I $\beta \mathrm{G}$, GFA bound $\beta$-galactosidase

\section{INTRODUCTION}

$\beta$-galactosidase (E.C.3.2.1.23) is a vital enzyme with diverse applications in molecular biology and industries (Kishore et al., 2012). It serves the dual purpose of catalyzing the hydrolysis of lactose into glucose and galactose, and in the production of galacto-oligosaccharides via a transgalactosylation reaction. It is widely present in microorganisms, plants and animals and finds extensive application in the food processing industry (Ansari et al., 2013). Its technological importance arises mainly due to the problems associated with whey disposal, lactose crystallization in frozen concentrated desserts and milk consumption by lactose-intolerant populations (Demirhan et al., 2010).

*To whom correspondence should be addressed 
Considerable improvements have been made in the recent past to obtain lactose hydrolyzed products (Panesar et al., 2010; Rhimi et al., 2010). Moreover, the time consuming and vast complexity involved in preparing immobilization matrices, greater cost of $\beta$-galactosidases and the complicated protocols of their isolation and purification typically accounts for $80 \%$ of the total manufacturing cost of an immobilized enzyme system (Zhang et al., 2010). In the recent past, $\beta$-galactosidases have been isolated from several plant materials for biocatalysis and were found to exhibit wide specificity, easy accessibility and high stability in solution (Biswas et al., 2003; Lee et al., 2003; Haider and Husain, 2007; Diwedi and Kayastha, 2009).

Enzymes are expensive commodities, which makes their reusability an important issue, thereby making their commercial exploitation economical. This obstruction can be addressed by coupling of enzyme with a suitable support material. Immobilized enzymes offer several advantages like enhanced stability, easier product recovery, protection of enzymes against inactivating agents and proteolysis (Grosova et al., 2008; Johnson et al., 2014). It also prevents the enzyme from denaturation and helps to retain the immobilized enzyme in biochemical reactors to further catalyze the subsequent feed and offer more economical use of biocatalysts in industry, waste treatment and in the development of bioprocess monitoring devices like biosensors (Betancor et al., 2008; Gurdas et al., 2010; Husain et al., 2011).

The present study revealed the functionalization of agarose via glutaraldehyde for the immobilization of Cicer arietinum $\beta$-galactosidase. The effect of various physical and chemical denaturants on the activity of soluble $\beta$-galactosidase $(\mathrm{S} \beta \mathrm{G})$ and glutaraldehyde functionalized agarose bound $\beta$-galactosidase (I $\beta \mathrm{G}$ ) has been investigated. The effect of product inhibition by galactose on soluble and immobilized $\beta$-galactosidase was monitored. Moreover, soluble and immobilized enzymes were evaluated for the hydrolysis of lactose from whey in stirred-batch reactors for varying time intervals. Reusability of immobilized enzyme was also investigated.

\section{MATERIALS AND METHODS}

\section{Materials}

Galactose, glucose oxidase-peroxidase kit, glutaraldehyde, and lactose were obtained from Sigma Chem. Co. (St. Louis, MO, USA). Agarose and $o$-nitrophenyl $\beta$-D-galctopyranoside were obtained from Merck. Chicken bean seeds were purchased from a local market. All other chemicals and reagents employed were of analytical grade and were used without further purification.

\section{Partial purification of $\beta$-galactosidase from Cicer arietinum}

$\beta$-galactosidase was isolated from Cicer arietinum with slight modifications according to the procedure described by Weixia et al. (1998). Chicken bean seeds (200 g) were soaked in water overnight and then germinated in a dark room for 3-5 days at $30{ }^{\circ} \mathrm{C}$. The cotyledons were removed and washed with distilled water twice. Collected cotyledons $(70 \mathrm{~g})$ were then homogenized in $140 \mathrm{ml}$ of $0.01 \mathrm{M}$ sodium phosphate buffer, $\mathrm{pH} 6.4$ containing $0.01 \%$ EDTA and $1 \%$ glycerol. The homogenate was kept at $4{ }^{\circ} \mathrm{C}$ and passed through four layers of muslin cheese cloth. The filtrate was then centrifuged at $10,000 \mathrm{xg}$ on a Remi R-24 refrigerated centrifuge for $30 \mathrm{~min}$ at $4{ }^{\circ} \mathrm{C}$. The clear supernatant was collected and the precipitate was discarded. After precipitating the supernatant with 0-30\% ammonium sulphate by overnight stirring, the solution was centrifuged at 10,000x $g$ for $10 \mathrm{~min}$ at $4{ }^{\circ} \mathrm{C}$. The precipitate was decanted and supernatant was again subjected to $0-70 \%$ ammonium sulfate fractionation for about $2 \mathrm{~h}$. The filtrate was finally centrifuged at $10,000 \mathrm{x} g$ for $10 \mathrm{~min}$ at $4{ }^{\circ} \mathrm{C}$. The precipitate collected was re-dissolved in $0.01 \mathrm{M}$ sodium phosphate buffer, $\mathrm{pH} 6.4$ and was dialyzed against the assay buffer.

\section{Surface functionalization of agarose by glutaraldehyde}

Agarose was pre-washed with deionized water and recovered by centrifugation at $2000 \mathrm{rpm}$ for $10 \mathrm{~min}$ at $32^{\circ} \mathrm{C}$. The washed agarose was then suspended in $100 \mathrm{mM}$ glutaraldehyde in a shaker at $200 \mathrm{rpm}$ for $4 \mathrm{~h}$. The activated support was removed by centrifugation, washed twice with deionized water to remove traces of glutaraldehyde and subsequently washed with assay buffer $(100 \mathrm{mM}$ sodium acetate buffer, $\mathrm{pH}$ 5.0) and used for further studies.

Adsorption of $\beta$-galactosidase on glutaraldehyde functionalized agarose

Functionalized agarose was incubated with $\beta$-galactosidase (1000 U) overnight at $32{ }^{\circ} \mathrm{C}$ with slow stirring. The unbound enzyme was removed by repeated washing with $100 \mathrm{mM}$ sodium acetate buffer $(\mathrm{pH}$ 5.0) to eliminate excess absorbed enzyme as the proteins can be coupled to the matrix by undesirable non-specific adsorption.

\section{Assay of $\beta$-galactosidase}

The hydrolytic activity of $\beta$-galactosidase was determined at $55{ }^{\circ} \mathrm{C}$ by measuring the release of $o$-nitrophenol from ONPG at $405 \mathrm{~nm}$. The reaction was performed by continuous shaking in an assay volume of 2.0 $\mathrm{ml}$ containing $1.7 \mathrm{ml}$ of $0.1 \mathrm{M}$ sodium acetate buffer, $\mathrm{pH}$ 
5.0, 2.0 U $\beta$-galactosidase and $0.2 \mathrm{ml}$ of $20 \mathrm{mM} \mathrm{ONPG}$. The reaction was stopped after $30 \mathrm{~min}$ by adding $2.0 \mathrm{ml}$ of 2.0 $\mathrm{M}$ sodium carbonate solution and product (o-nitrophenol) formation was measured spectrophotometrically at $405 \mathrm{~nm}$ (Ansari et al., 2015). One unit (1.0 U) of $\beta$-galactosidase activity is defined as the amount of enzyme that liberates 1.0 $\mu$ mole of o-nitrophenol $\left(\varepsilon_{\mathrm{m}}=4500 \mathrm{~L} / \mathrm{mol} / \mathrm{cm}\right)$ per min under standard assay conditions. The activity yield remaining after immobilization was defined as Activity yield (\%) = C/A x 100 and Immobilization yield (\%) =(A-B)/A x 100 where $\mathrm{A}$ is the total activity of enzyme added in the initial immobilization solution, B is the activity of the residual enzyme in the immobilization and washing solutions after the immobilization procedure and $\mathrm{C}$ is the activity of the immobilized enzyme.

\section{Effect of pH and temperature}

Enzyme activity of soluble and immobilized $\beta$-galactosidase preparations $(20 \mu \mathrm{L})$ was assayed in buffers of different $\mathrm{pH}(\mathrm{pH} 3.0-9.0)$. The buffers used were glycine- $\mathrm{HCl}(\mathrm{pH} 3.0)$, sodium acetate $(\mathrm{pH}$ 4.0-6.0) and Tris- $\mathrm{HCl}$ (7.0-9.0). The activity expressed at $\mathrm{pH} 5.0$ was considered as the control $(100 \%)$ for the calculation of the remaining percent activity.

The effect of temperature on soluble and immobilized $\beta$-galactosidase preparations $(20 \mu \mathrm{L})$ was studied by measuring their activity at various temperatures (30-80 $\left.{ }^{\circ} \mathrm{C}\right)$. The enzyme was incubated at various temperatures in $0.1 \mathrm{M}$ sodium acetate buffer, $\mathrm{pH} 5.0$, for $15 \mathrm{~min}$ and the reaction was stopped by adding $2.0 \mathrm{ml}$ of $2.0 \mathrm{M}$ sodium carbonate solution. The activity obtained at $55{ }^{\circ} \mathrm{C}$ was considered as the control $(100 \%)$ for the calculation of the remaining percent activity.

\section{Reusability and half-life of I $\beta$ G}

I $\beta G(100 \mu \mathrm{L})$ was taken in triplicate for assaying the activity of enzyme by stopping the reaction with $2.0 \mathrm{ml}$ of $2.0 \mathrm{M}$ sodium carbonate solution after $30 \mathrm{~min}$. After each assay, immobilized enzyme was taken out from assay tubes and was washed and stored in $0.1 \mathrm{M}$ sodium acetate buffer, pH 5.0, overnight at $4{ }^{\circ} \mathrm{C}$ for 6 successive days. The activity determined on the first day was considered as the control (100\%) for the calculation of the remaining percent activity.

Half life $\left(t_{1 / 2}\right)$ is the time required for the activity of an enzyme to reach half of its original value. It was calculated by measuring the activity of immobilized $\beta$-galactosidase $(500 \mu \mathrm{L})$ in $5.0 \% \mathrm{w} / \mathrm{w}$ initial lactose concentration at 55 ${ }^{\circ} \mathrm{C}$.

\section{Effect of galactose mediated product inhibition}

The effect of galactose $(1.0 \%-5.0 \%, \mathrm{w} / \mathrm{v})$ was measured for $1 \mathrm{~h}$ on the activity of soluble and immobilized $\beta$-galactosidase preparations $(20 \mu \mathrm{L})$ in $0.1 \mathrm{M}$ sodium acetate buffer, $\mathrm{pH}$ 5.0. The activity of the enzyme without added galactose was considered as the control (100\%) for the calculation of the remaining percent activity.

\section{Hydrolysis of whey lactose by soluble and immobilized $\beta$-galactosidase}

Whey $(250 \mathrm{~mL})$ was independently treated with soluble and immobilized $\beta$-galactosidase $(200 \mathrm{U})$ in a stirred batch process at $55^{\circ} \mathrm{C}$. The aliquot of $250 \mu \mathrm{l}$ was taken at indicated time intervals for $10 \mathrm{~h}$ for the formation of glucose by the glucose oxidase-peroxidase assay kit.

\section{Statistical analysis}

Each value represents the mean for three independent experiments performed in triplicates, with an average standard deviation $<5 \%$. The data expressed in various studies was plotted using Sigma Plot-9 and expressed with standard deviation of error $( \pm)$. Data was analyzed by oneway ANOVA. P-values $<0.05$ were considered statistically significant.

\section{RESULTS AND DISCUSSION}

\section{Matrix selectivity}

Agarose is a linear polysaccharide containing repeat units of agarobiose (a disaccharide consisting of 1,3-linked D-galacto-pyranose and 1,4-linked 3,6-anhydro-Lgalactopyranose). It serves as an excellent matrix for enzyme immobilization due to its high porosity and gel formation tendency even at low concentrations. Apart from its easy commercial availability, it exhibited excellent hydrophilic nature, ease of derivatization and absence of charged groups, which helps in preventing nonspecific adsorption of substrate and products (Prakash and Jaiswal, 2011). Moreover, the use of glutaraldehyde as a crosslinking agent is considered as Generally Recognized as Safe apart from its low cost to impart stability to immobilized enzymes (Guisan et al, 2013).

\section{Immobilization of $\boldsymbol{\beta}$-galactosidase}

$\beta$-galactosidase from an inexpensive source, Cicer arietinum, was exploited to immobilize it on glutaraldehyde functionalized agarose (GFA) for the hydrolysis of lactose from whey in batch reactors. Higher immobilization yield of $83 \%$ was obtained for the enzyme due to the surface modification of the matrix by glutaraldehyde as a crosslinking agent (Table 1). Previous investigators have obtained an immobilization yield of $72 \%$ and $78 \%$ for almond and apricot $\beta$-galactosidase, respectively (Ansari and Husain, 2011; Ansari et al., 2014). 
Table 1. $\beta$-galactosidase immobilized on glutaraldehyde functionalized agarose

\begin{tabular}{|c|c|c|c|c|}
\hline \multicolumn{3}{|c|}{ Enzyme activity (units) } & \multirow{2}{*}{$\begin{array}{c}\text { Activity Yield (\%) } \\
\text { C/A X } 100\end{array}$} & \multirow{2}{*}{$\begin{array}{c}\text { Immobilization Yield (\%) } \\
\text { (A-B)/A x } 100\end{array}$} \\
\hline Added (A) & Unbound (B) & Immobilized (C) & & \\
\hline 1000 & 170 & 680 & $68 \pm 1.9$ & $83 \pm 2.7$ \\
\hline
\end{tabular}

\section{Effect of pH and temperature}

Higher stability of GFA bound $\beta$-galactosidase against various forms of inactivation may be related to the specific and strong binding of the enzyme with the support, which prevents the unfolding/denaturation of the enzyme. It has been widely accepted that immobilized enzyme exhibit enhanced $\mathrm{pH}$ and temperature stability as compared to their free counterparts due to the conformational stability attained by them as a result of bond formation between enzyme and matrix (Elnashar and Yassin, 2009; Park and Oh, 2010). Immobilized enzyme showed no change in pH-optima but exhibited remarkable broadening in the $\mathrm{pH}$-activity profiles as compared to the native enzyme. Moreover, the free enzyme showed $79 \%$ activity at $\mathrm{pH} 4.0$, whereas the immobilized $\beta$-galactosidase retained 91\% activity under similar experimental conditions (Fig 1). Similar results were obtained for $\beta$-galactosidase immobilized on nanodiamonds by Ansari and coworkers. It was observed that immobilized enzyme retained greater fractions of catalytic activity at both lower and higher $\mathrm{pH}$ ranges as compared to the soluble counterpart (Ansari et al., 2015). This study exhibited $68 \%$ and $45 \%$ activity at $\mathrm{pH} 4.0$ and $\mathrm{pH} 6.0$, respectively. However, when this enzyme was immobilized on diamond nanoparticles, it exhibited a significant improvement in activity of $92 \%$ and $82 \%$ activity under similar incubation conditions. Moreover, $\beta$-galactosidase from almond exhibited $40 \%$

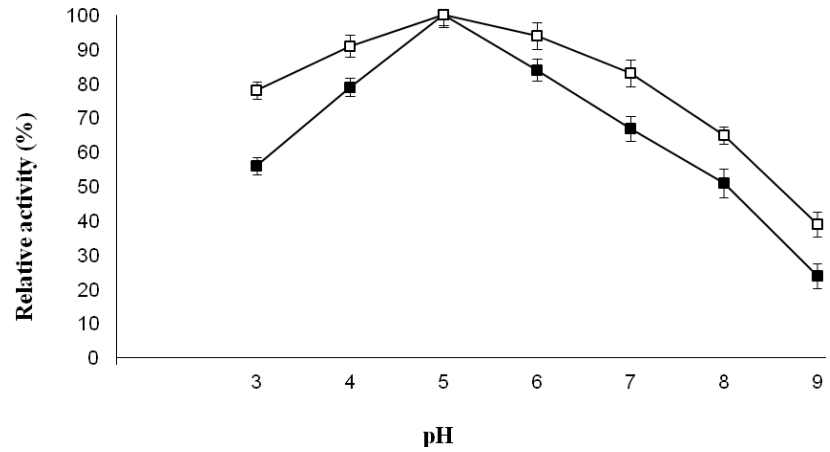

Figure 1. $\mathrm{pH}$ activity profiles for soluble and immobilized $\beta$-galactosidase. The activity of soluble and immobilized $\beta$-galactosidase $(20 \mu \mathrm{L})$ was measured in buffers of various $\mathrm{pH}$ (3.0-9.0). The buffers used were glycine- $\mathrm{HCl}(\mathrm{pH} 3.0)$, sodium acetate ( $\mathrm{pH} 4.0-6.0)$, and Tris- $\mathrm{HCl}(\mathrm{pH} 7.0-9.0)$. Molarity of each buffer was $0.1 \mathrm{M}$. The activity at $\mathrm{pH} 5.0$ was taken as control $(100 \%)$ for the calculation of remaining percent activity. The symbols show soluble ( $\square)$ and immobilized ( $\square) \beta$-galactosidase. and $70 \%$ activity at $\mathrm{pH} 4.0$ and $\mathrm{pH} 6.0$ as compared to $84 \%$ and $92 \%$ activity for immobilized enzyme, respectively, under identical conditions (Ansari and Husain, 2011). The temperature-activity profile for soluble and immobilized $\beta$-galactosidase is shown in Fig 2. Immobilization does not alter the optimal temperature for activity of the enzyme.

However, immobilized $\beta$-galactosidase retained greater fractions of catalytic activity at other temperatures as compared to soluble enzyme. It was noted that soluble $\beta$-galactosidase showed $41 \%$ activity at $70{ }^{\circ} \mathrm{C}$, whereas the immobilized $\beta$-galactosidase retained $67 \%$ activity at the same temperature. Immobilization also resulted in improved stability of immobilized $\beta$-galactosidase for glutaraldehyde-activated chitosan (Klein et al., 2013). The probable reason for this may be that covalent binding and crosslinking provided a more rigid external backbone for $\beta$-galactosidase immobilization. It has been shown earlier that almond $\beta$-galactosidase exhibited $48 \%$ and $78 \%$ activity at $40{ }^{\circ} \mathrm{C}$ and $60{ }^{\circ} \mathrm{C}$, while immobilized enzyme retained $86 \%$ and $92 \%$ activity under identical incubation conditions (Ansari and Husain, 2011).

\section{Reusability and operational stability of immobilized $\beta$-galactosidase}

The operational stability of GFA bound $\beta$-galactosidase was investigated by measuring its half-life $\left(t_{1 / 2}\right)$ at its optimal temperature. The $\mathrm{t}_{1 / 2}$ was found to be $28 \mathrm{hrs}$ at $55^{\circ} \mathrm{C}$,

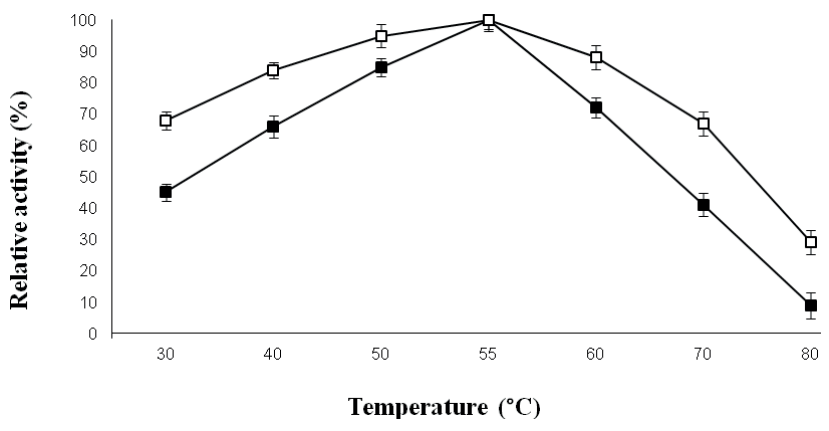

Figure 2. Temperature activity profiles of soluble and immobilized $\beta$-galactosidase. Soluble and immobilized $\beta$-galactosidase (20 $\mu \mathrm{L})$ activity was assayed in $0.1 \mathrm{M}$ sodium acetate buffer, $\mathrm{pH}$ 5.0 , at various temperatures $\left(30-80{ }^{\circ} \mathrm{C}\right)$ for $15 \mathrm{~min}$. The activity obtained at $50{ }^{\circ} \mathrm{C}$ was considered as the control (100\%) for the calculation of the remaining percent activity. For symbols, please refer to Figure 1 legend. 
whereas the soluble enzyme was completely inactivated after $48 \mathrm{hrs}$ under similar incubation conditions. Earlier, Warmerdam et al. (2013) had reported the $t_{1 / 2}$ of Bacillus circulans $\beta$-galactosidase as $220 \mathrm{~h}$ and $13 \mathrm{~h}$ at 25 and $40^{\circ} \mathrm{C}$, respectively. The half-life for Bacillus stearothermophilus $\beta$-galactosidase was observed as $50 \mathrm{~h}$ and $9 \mathrm{~h}$ at $65^{\circ} \mathrm{C}$ and $70^{\circ} \mathrm{C}$, respectively (Chen et al., 2008). In another study, the half-life of Talaromyces thermophilus $\beta$-galactosidase was determined to be $8 \mathrm{~h}$ and $27 \mathrm{~h}$ at $50^{\circ} \mathrm{C}$ for the free and immobilized enzymes, respectively (Nakkharat and Haltrich, 2006). Other major problems generally associated with immobilized $\beta$-galactosidase systems include product mediated inhibition, microbial contamination, protein adherence and channeling (Kaur et al., 2009). Figure 3 shows the inhibitory effect of galactose on the activity of soluble and immobilized $\beta$-galactosidase. Soluble $\beta$-galactosidase showed $41 \%$ activity in the presence of $3.0 \%$ galactose, while the immobilized enzyme exhibited much higher enzyme activity, $80 \%$ at the same concentration of galactose.

$\beta$-galactosidases are expensive commodities, which makes their reusability an important issue thereby making their commercial exploitation economical (Ansari et al., 2015). This obstruction was addressed by coupling enzyme with a suitable support material, agarose. Immobilized $\beta$-galactosidase showed $75 \%$ and $70 \%$ of the initial activity, after its $5^{\text {th }}$ and $6^{\text {th }}$ repeated use, respectively (Fig 4). In view of the stability offered by agarose, it appeared to be a useful immobilized matrix for Cicer arietinum $\beta$-galactosidase in order to hydrolyze whey lactose in batch reactors.

\section{Lactose hydrolysis in batch process}

Hydrolysis of whey lactose in a batch reactor showed that the rate of hydrolysis was greater in the case of free enzyme for first few hours as compared to the immobilized $\beta$-galactosidase (Fig 5). This was due to the fact that soluble enzyme was more accessible for hydrolysis of lactose for the first few hours, but after prolonged time intervals the rate of lactolysis decreased much faster. This phenomenon of inhibition of $\beta$-galactosidase by the product has been explained earlier (Ansari et al., 2013; 2015). It has been evaluated that lactose hydrolysis in whey by free enzyme was $39 \%$ in $4 \mathrm{~h}$ but a maximum hydrolysis of $71 \%$ was achieved in $9 \mathrm{~h}$. Similarly, it was noted that the maximum hydrolysis of whey lactose by immobilized enzyme was $83 \%$ after 8 h under identical incubation conditions. The rate of lactose hydrolysis in whey depends on the activity of $\beta$-galactosidase, which in turn depends on the reaction conditions like $\mathrm{pH}$, temperature, concentration of enzyme and processing time (Panesar et al., 2007). Our results indicated that GFA bound $\beta$-galactosidase showed higher lactose hydrolysis in whey because it exhibited greater stability in the $\mathrm{pH}$ ranges similar to the $\mathrm{pH}$ values of

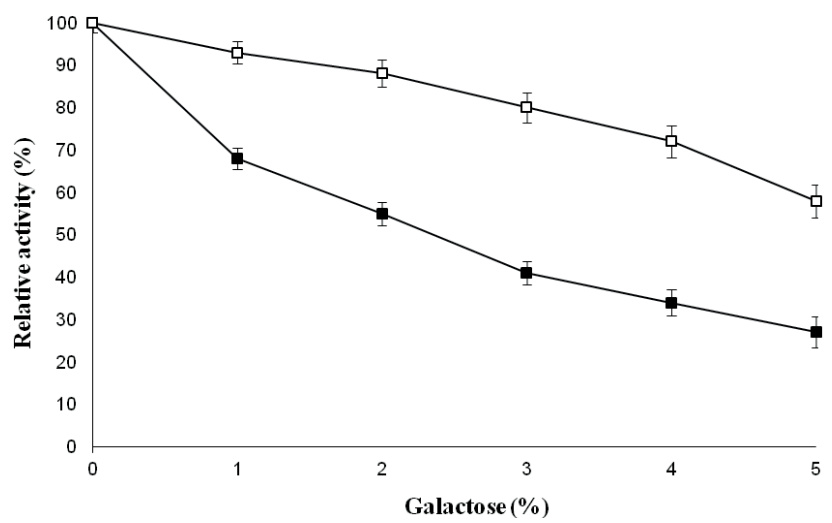

Figure 3. Effect of galactose on soluble and immobilized $\beta$-galactosidase. Effect of increasing concentrations (1.0-5.0\%, $\mathrm{w} / \mathrm{v})$ of galactose on soluble and immobilized $\beta$-galactosidase $(20 \mu \mathrm{L})$ was independently measured in $0.1 \mathrm{M}$ sodium acetate buffer, $\mathrm{pH} 5.0$, for $1 \mathrm{~h}$ at $55^{\circ} \mathrm{C}$. The activity of enzyme without added galactose was considered as the control (100\%) for the calculation of the remaining percent activity at various concentrations of galactose. For symbols, please refer to Figure 1 legend.

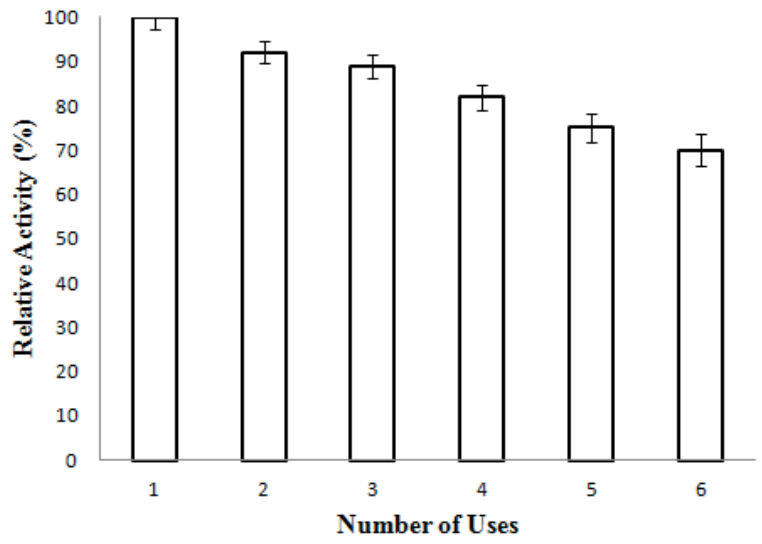

Figure 4. Reusability of immobilized $\beta$-galactosidase. Reusability of GFA bound $\beta$-galactosidase $(100 \mu \mathrm{L})$ was monitored for 6 successive days. The aliquots were taken in triplicate and were assayed for the remaining percent activity. The activity determined on the first day was taken as the control (100\%) for the calculation of the remaining activity after each use.

whey, i.e., 4.5-5.0 (Fig 1). It has been well documented that plant and fungal $\beta$-galactosidases having acidic $\mathrm{pH}$ optima are suitable for processing acid whey and whey permeate, whereas the enzymes from yeasts and bacteria exhibiting neutral $\mathrm{pH}$-optima are suitable for processing milk. It has been reported earlier that $\beta$-galactosidase from Kluveromyces fragilis hydrolyzes whey permeate containing $5 \%$ lactose into $96 \%$ lactose in $48 \mathrm{~h}$ at $35^{\circ} \mathrm{C}$ and pH 7.0 (Szczodrak, 2000). Zhou and Chen (2001) 


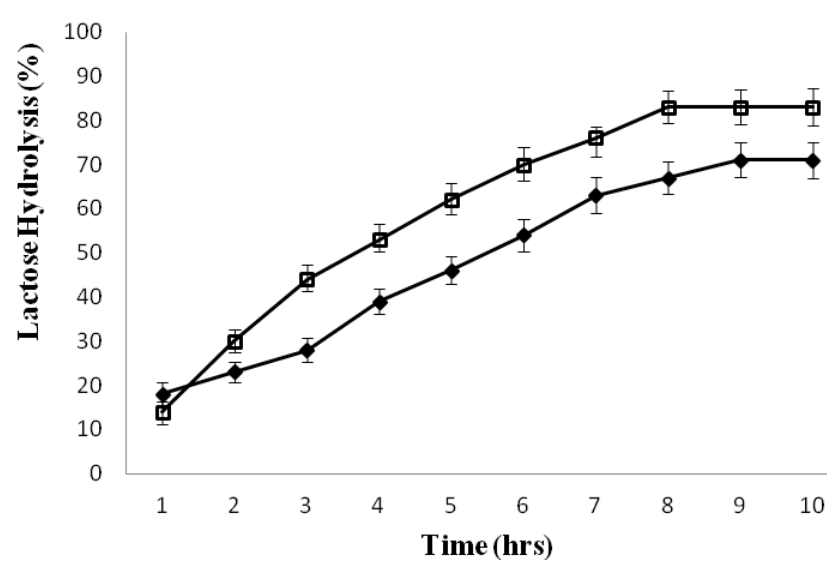

Figure 5. Hydrolysis of lactose from whey in batch processes at $55^{\circ} \mathrm{C}$

also reported that $\beta$-galactosidase from Kluveromyces lactis immobilized onto the surface of graphite using glutaraldehyde as a crosslinking reagent hydrolyzed 5\% (w/v) lactose to $70 \%$ within $3 \mathrm{~h}$ at $37^{\circ} \mathrm{C}$ but when the temperature was increased to $50{ }^{\circ} \mathrm{C}$, only $50 \%$ of the lactose was hydrolyzed after $3 \mathrm{~h}$. It was observed earlier that Aspergillus oryzae $\beta$-galactosidase immobilized on concanavalin A-cellulose exhibited $64 \%$ lactose hydrolysis at $60{ }^{\circ} \mathrm{C}$ after $1 \mathrm{~h}$ in a batch process (Ansari and Husain, 2010).

\section{CONCLUSION}

GFA provided significantly higher stability to Cicer arietinum $\beta$-galactosidase against broader ranges of $\mathrm{pH}$ and temperature as compared to its soluble counterpart. In view of its utility in lactose hydrolysis in a batch process, this preparation could be exploited for converting whey lactose in batch reactors in a convenient and cheaper way.

\section{ACKNOWLEDGMENTS}

The authors declare that there is no competing interest for this study.

\section{REFERENCES}

Ansari, S.A. and Husain, Q., Lactose hydrolysis by $\beta$-galactosidase immobilized on concanavalin A-cellulose in batch and continuous mode. Journal of Molecular Catalysis B: Enzymatic 63(15), 68 (2010).

Ansari, S.A., Husain, Q., Bioaffinity based immobilization of almond (Amygdalus communis) $\beta$-galactosidase on Con A-layered calcium alginate-cellulose beads:
Its application in lactose hydrolysis in batch and continuous mode. Iranian Journal of Biotechnology, 9(4), 290 (2011).

Ansari, S.A., Satar, R., Chibber, S. and Khan, M.J., Enhanced stability of Kluyveromyces lactis $\beta$ galactosidase immobilized on glutaraldehyde modified multiwalled carbon nanotubes. Journal of Molecular Catalysis B: Enzymatic, 97(2), 258 (2013).

Ansari, S.A., Satar, R., Zaidi, S.K., Khan, M.J., Naseer, M.I., Alqahtani, M.H., Maskat, M.Y. PJCT Future applications of apricot (Prunus armeniaca kaisa) $\beta$-galactosidase in dairy industry. Polish Journal of Chemical Technology, 16(4), 6 (2014).

Ansari, S.A., Satar, R., Zaidi, S.K., Alqahtani, M.H., Naseer, M.I., Karim, S. and Rasool, M., Nanodiamonds as an effective and novel matrix for immobilizing $\beta$ galactosidase. Food and Bioproduct Processing, 95(4), 298 (2015).

Betancor, L., Luckarift, R., Seo, H., Brand, O. and Spain, J.C., Three-dimensional immobilization of $\beta$-galactosidase on a silicon surface. Biotechnology and Bioengineering, 99(4), 261 (2008).

Biswas, S., Kayastha, A.M. and Seckler, R., Purification and characterization of a thermostable $\beta$-galactosidase from kidney beans (Phaseolus vulgaris L.) cv. PDR14. Journal of Plant Physiology, 160(16), 327 (2003).

Chen, W., Chen, H., Xia, Y., Zhao, J., Tian, F., Zhang, H. Production, purification and characterization of a potential thermostable galactosidase for milk lactose hydrolysis from Bacillus stearothermophilus. Journal of Dairy Science 91(4), 1751 (2008).

Demirhan, E., Apar, D.K. and Ozbek, B., A modelling study on hydrolysis of whey lactose and stability of $\beta$-galactosidase. Korean Journal of Chemical Engineering, 27(6), 536 (2010).

Diwedi, A. and Kayastha, A.M., Stabilization of $\beta$-galactosidase (from peas) by immobilization onto amberlite MB-150 beads and its application in lactose hydrolysis. Journal of Agriculture and Food Chemistry, 57(22), 682 (2009).

Elnashar, M.M.M. and Yassin, MA., Lactose hydrolysis by $\beta$-galactosidase covalently immobilized to thermally stable biopolymers. Applied Biochemistry Biotechnology, 159(24), 426 (2009).

Grosova, Z., Rosenberg, M. and Rebros, M., Perspectives and applications of immobilized $\beta$-galactosidase in food industry - A review. Czech Journal of Food Science, 26(35), 1 (2008).

Guisan, J.M., Betancor, L., Fernandez-Lorente, G., Chapter 54 Immobilized enzymes IN Upstream Industrial Biotechnology, 2(2), 1201 (2013). 
Gurdas, S., Gulec, H.A. and Mutlu, M., Immobilization of Aspergillus oryzae $\beta$-galactosidase onto Duolite A568 resin via simple adsorption mechanism. Food Bioprocess Technology, 5(13), 904 (2010).

Haider, T. and Husain, Q., Preparation of lactose free milk by using salt fractionated almond (Amygdalus communis) $\beta$-galactosidase. Journal of Science and Food Agriculture, 87(14), 1278 (2007).

Husain, Q., Ansari, S.A., Alam, F. and Azam, A., Immobilization of Aspergillus oryzae $\beta$ galactosidase on $\mathrm{ZnO}$ nanoparticles via simple adsorption mechanism. International Journal of Biological Macromolecules, 49(23), 37 (2011).

Johnson, B.J., Algar, W.R., Malanoski, A.P., Ancona, M.G. and Medintz, I.L., Understanding enzymatic acceleration at nanoparticle interfaces: Approaches and challenges. Nano Today, 9(3), 102 (2014).

Kaur, G., Panesar, P.S., Bera, M.B. and Kumar, H., Hydrolysis of whey lactose using CTAB-permeabilized yeast cells. Bioprocess Biosystems Engineering, 32(10), 63 (2009).

Klein, M.P., Fallavena, L.P., Schoffer, J.N., Ayub, M.A., Rodrigues, R.C., Ninow, J.L., Hertz, P.F. High stability of immobilized $\beta$-galactosidase for lactose hydrolysis and galactooligosaccharides synthesis. Carbohydrate Polymers 95(2), 465 (2013).

Kishore, D., Talat, M., Srivastav, O.N. and Kayastha, A.M., Immobilization of $\beta$-Galactosidase onto functionalized graphene nano-sheets using response surface methodology and its analytical applications. Plos One, 7(7), e40708 (2012).

Lee, D.H., Kang, S.G., Suh, S.G. and Byun, J.K., Purification and characterization of $\beta$-galactosidase from peach (Prunus persica). Molecular Cells, 15(21), 68 (2003).

Nakkharat, P., Haltrich, D. Lactose hydrolysis and formation of galactooligosaccharides by a novel immobilized $\beta$-galactosidase from the thermophilic fungus Talaromyces thermophilus. Applied Biochemistry and Biotechnology 129(6), 215 (2006).
Panesar, P.S., Kumari, S. and Panesar, R., Potential applications of immobilized $\beta$-galactosidase in food processing industries. Enzyme Research, 2010(3), 473137 (2010).

Panesar, R., Panesar, P.S., Singh, R.S., Kennedy, J.F. and Bera, M.B., Production of lactose hydrolyzed milk using ethanol permeabilized yeast cells. Food Chemistry, 101(3), 786 (2007).

Park, A. and Oh, D., Effects of galactose and glucose on the hydrolysis reaction of a thermostable $\beta$-galactosidase from Caldicellulosiruptor saccharolyticus. Applied Microbiology Biotechnology, 85(11), 1427 (2010).

Prakash, O., Jaiswal, N., Immobilization of a thermostable $\alpha$-amylase on agarose and agar matrices and its application in starch stain removal. World Applied Sciences Journal, 13(4), 572 (2011).

Rhimi, M., Boisson,A., Dejob, M., Boudebouze, S., Maguin, E., Haser, R. and Aghajari, N., Efficient bioconversion of lactose in milk and whey: immobilization and biochemical characterization of $\beta$-galactosidase from the dairy Streptococcus thermophilus LMD9 strain. Research Microbiology, 161(3), 515 (2010).

Szczodrak, J., Hydrolysis of lactose in whey permeate by immobilized $\beta$-galactosidase from Kluveromyces fragilis. Journal of Molecular Catalysis B Enzymatic, 10(7), 631 (2000).

Warmerdam, A., Boom, R.M. and Janssen A.E.M., $\beta$-galactosidase stability at high substrate concentrations. Springer Plus 50(2), 402 (2013).

Weixia, T., Sufang, S., Shaoli, N. and Xuyuan, L., Immobilization of $\beta$-galactosidase from Cicer arietinum (gram chicken bean) and its catalytic actions. Food Chemistry, 64(16), 495 (1998).

Zhang, S., Gao, S. and Gao, G., Immobilization of $\beta$-galactosidase onto magnetic beads. Applied Biochemistry Biotechnology, 160(1), 1386 (2010).

Zhou, Q.Z.K. and Chen, X.D., Immobilization of $\beta$-galactosidase on graphite surface by glutaraldehyde. Journal of Food Engineering, 48(13), 69 (2001). 